\title{
The NeW TRADition OF PUTU WIJAYA
}

\author{
Ellen Rafferty
}

\section{Introduction}

Putu Wijaya is one of Indonesia's most prominent and prolific authors, contributing numerous novels, short stories, dramas, and film scripts to Indonesian literature. ${ }^{1} \mathrm{He}$ is Balinese by birth and Jakartan by choice having spent the past twenty years there. The marriage of Balinese and Jakartan cultures is reflected in his literary style which is characterized by a departure from the conventions of realism, an eagerness to borrow from traditional and folk genres, ${ }^{2}$ and a black and biting humor. This style draws on elements commonly found in regional genres, such as wayang, arja, ludruk, ketoprak, lenong, and Srimulat, ${ }^{3}$ creating artistic forms that are reminiscent of Javanese and Balinese cultures, while remaining rooted in contemporary Jakarta. His language is colloquial, peppered with Jakartanese and Javanese expressions; his syntax is bare, direct, even shockingly abrupt. His themes, often arising out of urban settings, include feelings of alienation,

${ }_{1}$ Putu Wijaya was a Fulbright scholar at the University of Wisconsin, Madison during the 1985-1986 academic year. I am grateful to him and to two anonymous readers for their comments on this essay.

2 By "traditional genres" I mean the contemporary cultural expressions of ethnic groups such as Javanese, Sundanese, Balinese, etc., not the performance traditions of past eras. Since performance traditions may be learned and performed by anyone of a particular region, the Indonesian term kesenian daerah or "regional arts" is a more appropriate term because it avoids the distinction between ethnic affiliation and regional group identity. The term "folk" characteristically is used to identify cultural performances associated with the lower class. There is a blurring of the distinction between traditional and folk genres in Indonesia as modern forms borrow from both folk and classical performance traditions. I use the terms "regional genres" or "regional art forms" to identify both traditional and folk genres.

${ }^{3}$ Wayang is the traditional puppet theater of Java and Bali based on adaptations of the Indian epics, the Mahabharata and Ramayana. Ludruk, a contemporary folk drama, arose in the early twentieth century in Surabaya, and its all male cast uses Javanese language. Its popularity among the masses derives from its humor and treatment of modern social issues. Ketoprak, a dance-drama of Central Java, developed in the late nineteenth century and relates stories and legends of the colonial period. Srimulat which was established in the 1930s is a contemporary folk-drama that relies on improvisation and comedy routines. Arja is a traditional Balinese romantic dance-opera, presenting legends of the East Java kingdoms. Lenong is a folk-drama established in the early twentieth century which relates the history of the Betawi people of Jakarta. 
tensions between traditional and modern obligations, and fears of rapidly changing cultural norms. Not surprisingly, his intended audiences are those experiencing a modernizing Indonesia, often educated, urban young adults.

For Putu, literature is a means of creating a dialogue between author and audience, not a means of delivering a specific message. His strategy for achieving his goal is to create a familiar setting that combines elements from regional genres within a modern context. Although Putu's audiences may not be familiar with traditional genres, they have probably been exposed to a lack of realism, stylized characters, and the humor of the absurd in comic book presentations of wayang stories, in dagelan (comedy) routines, in movies such as Raja Copet (King of the Pickpockets) where the influence of Srimulat is evident, and in other adaptations from traditional and folk genres in the mass media.

Putu's literary style alternately encourages and frustrates the adoption of a realistic interpretation. The discourse is organized in order to deceive and disturb the reader, to encourage the reader to question accepted norms. In 1984 Putu commented on the function of literature as follows:

A composition ... becomes just a tool which is never more important than the individual readers it will reach. But as a perfect tool, it must be able to overcome the constraints of time and place so that it can be used by people of all times, of all classes, of all beliefs, of all groups-the noble as well as the amoral. And it must not contain just one possibility. It must be densely packed like a jungle, like Arjuna Sasrabahu with a thousand faces that can simultaneously attack in every direction [my translation]. 4

The above quote shows Putu to be a universalist - one who believes artists can transcend ethnic and national boundaries through their literary works. He hopes his works will speak to a variety of people, not just to Jakartan youth or to a particular class or ethnic group of Indonesia, but to peoples of various socio-cultural backgrounds in Indonesia and abroad. By basing his stories on common emotions, fears, and crises, Putu strives to speak to the ethnic and cultural diversity of a rapidly changing Indonesia as well as to other modern and modernizing societies. Putu's success in achieving this goal could only be ascertained through an investigation of audience composition and their interpretations. ${ }^{5}$

His plays aim to do more than entertain audiences with the exploits and tragedies of his characters-Oki, Pian, and Bima. In his drama Gerr, ${ }^{6}$ the audience is asked whether society is unfairly ostracizing individuals and demanding conformity. These questions demand thought-an investment of time and energy; and some audience members may not care to make such an investment. They may decide merely to enjoy the comedy of

\footnotetext{
${ }^{4}$ Putu Wijaya, "Konsep," in Dua Puluh Sastrawan Bicara, ed. Dewan Kesenian Jakarta (Jakarta: Sinar Harapan, 1984), pp. 82-83. "Sebuah karangan ... menjadi alat saja yang tak pernah lebih penting dari manusia pembaca yang akan dihubungi. Tetapi sebagai alat yang sempurna ia harus memenuhi persyaratan yang bisa menembus ruang dan waktu sehingga dapat dipakai oleh manusia segala zaman, manusia segala tingkatan, manusia dari segala paham, dari segala jenis manusia, yang luhur maupun yang bejat. Dan ia juga mestinya tidak hanya mengandung satu kemungkinan. Ia harus penuh sesak bagai rimba, bagai Arjuna Sasrabahu dengan seribu muka yang bisa menerjang ke segala arah dengan serentak."

5 Such a study is needed in order to understand the relevance of Putu's work, but I do not attempt to address this question here.

6see Putu Wijaya, Gerr (Jakarta: Balai Pustaka, 1986) and its English translation Geez! in Putu Wijaya in Performance: A Script and Study of Indonesian Theatre, ed. Ellen Rafferty, Center for Southeast Asian Studies,
} 
Bima as he runs from his pursuers who chase him back to his coffin, or the tragedy of Oki who, afraid of inflicting pain on others, scales the flagpole where he later dies, a victim of his own fears. ${ }^{7}$

Putu's intended audience includes those willing to pursue the story, to explore themes and ponder questions of social and/or philosophical import, seeing anew the customs of their societies. While the audience for Putu's writings is primarily an educated elite able to make the transition from a distorted (unreal) setting and plot to their own concrete situations, the audiences of his plays may be broader; they may include a less intellectually oriented group. Prior to Putu's departure for the United States in 1985, his plays were generally performed at Taman Ismail Marzuki (TIM) where audiences consisted primarily of Jakartan youth interested in the arts. Since his return to Indonesia in 1988, he has performed both at the Graha Bhakti Budaya at TIM and at the Gedung Kesenian in Jakarta. As ticket prices rise both inside and outside TIM, the composition of theater audiences is shifting from the youthful groups of the past to an older, more established group. In light of this shift, perhaps Putu will begin to address this new audience. $^{8}$

\section{The New Tradition?}

The desire to incorporate traditional modes of expression in contemporary Indonesian arts is not unique to Putu. Interest in the use of elements from regional art forms arose, to a large extent, in the environment created by the establishment of Taman Ismail Marzuki ${ }^{10}$ in 1968 . In the early years of TIM, experimentation was most prominent in the field of theater-a field inherently more accessible to a wide spectrum of society, and open to influences from oral performance traditions. ${ }^{11}$ Some of the pioneers in the creation of new theater traditions were W.S. Rendra, 12 Arifin C. Noer, and Sardono; later, artists such as Putu Wijaya, Ikranagara, and Wisran Hadi joined them. A common thread linking these authors is a conscious and/or unconscious debt to their cultural backgrounds as evidenced by the use of elements from regional genres.

monograph no. 4 (Madison: University of Wisconsin, 1989).

${ }^{7}$ See "If He Could Choose Again," in Bomb: Indonesian Short Stories by Putu Wijaya, ed. Ellen Rafferty and Laurie J. Sears (Madison, WI: University of Wisconsin Center for Southeast Asian Studies, 1988), pp. 32-43.

${ }^{8}$ Putu hints at a willingness to adapt to a new audience in an interview by Burhan Piliang, "Strategi Putu," in Tempo, November 5, 1988, p. 71.

9Putu first used the term "New Tradition" in lectures at the University of Wisconsin, Madison, in 1985 to identify the contemporary Indonesian arts not modeled on Western genres. These Indonesian forms are a product of a historical process, expressing aesthetic principles of contemporary Indonesia.

${ }^{10} \mathrm{TIM}$ is an arts center which was established in 1968 by the Special District of Jakarta under the leadership of Governor Ali Sadikin. It became an important forum for traditional, modern, and international artists, stimulating creativity not only because of the modern and subsidized facilities but also because of the freedom from censorship.

${ }^{11}$ For a negative view of the new directions in contemporary Indonesian theater see Mh. Rustandi Kartakusuma, "Sastra Tanpa Kebanggaan Nasional," in Budaja Djaja 73 (June 1974): 327-34, which expresses the opinion that the new theater is merely an imitation of Western theater and does not speak to the Indonesian populace.

12For a discussion of Rendra's contribution to the development of new traditions see Dami N. Toda, 'Teater Baru Indonesia," in Hamba Hamba Kebudayaan, ed. Dami N. Toda (Jakarta: Sinar Harapan, 1984), pp. 34-40; and Umar Kayam, "Penghayatan Seni dan Eksplorasi Seni," in Seni, Tradisi, Masyarakat, ed. Umar Kayam (Jakarta: Sinar Harapan, 1981), pp. 22-37. 
Putu labeled contemporary artistic expressions that are inspired by, but not tied to, regional art forms as the New Tradition. This New Tradition, which began to flourish at TIM in the late 1960s and early 1970s, is no longer confined to theater. The flavor of regional culture combined with the expression of modernity in Indonesian arts is evidenced in the short stories and novels of Yudhistira, Danarto, Korrie Layun Rampan, and Linus Suryadi among others. The popularity of public readings of literature and the influence of Javanese lexicon and grammatical structure on the Indonesian language ${ }^{13}$ both demonstrate the complementary nature of regional and modern influences on emergent Indonesian culture.

Umar Kayam's description of the tensions between regional and modern art styles which he sees in the works of Rendra is applicable to other experimental writers who adapt regional ways of speaking to broader audiences:

W.S. Rendra identifies himself as a rebel but at the same time a traditionalist. He sees himself as a rebel because he consciously desires to play the role of a creative artist who wants, from time to time, to shake up customs that have become frozen. . .. [He] wants to see the society refreshed by new thoughts and opinions which can stimulate the society to continue to be dynamic [my translation]. ${ }^{14}$

The experimental writers of the New Tradition strive to entertain the public with new (perhaps national) forms, while maintaining continuity with local symbols and styles of performing.

The trend toward incorporation of elements from regional art forms in modern literature and performance traditions sharply contrasts with earlier attitudes. In the past, these art forms were regarded as lacking in modernity and status. 15 Prior to independence, there was a strong tendency among those writing in Malay/Indonesian to emulate Dutch/Western aesthetic principles. In the early years of independence, artists strove to imitate Western genres-novel, short story, and drama. There was apprehension that the assertion of ethnic identity in artistic expression would be divisive in a newly emerging nation. By the late 1970s, however, the expression of regional identity was no longer considered threatening. On the contrary, in the $1980 \mathrm{~s}$ it is regarded as an enriching element, one valued in the development of distinctive Indonesian art forms.

\section{Putu's Literary Style}

A number of prominent features of Putu's style are explored below, as well as his place in the development of contemporary Indonesian literature. Examples from Putu's

\footnotetext{
${ }^{13}$ See J. Joseph Errington, "Continuity and Change in Indonesian Language Development," Journal of Asian Studies, 45, 2 (1986): 341-45.

${ }^{14}$ Kayam, "Penghayatan Seni," p. 35. "W.S. Rendra menempatkan dirinya sebagai seorang 'urakan' tetapi sekaligus juga seorang 'tradisionalis'. Dia melihat dirinya sebagai urakan karena dia dengan sadar ingin memainkan peranannya sebagai seorang seniman kreatif yang ingin sewaktu-waktu menggoncangkan kelaziman-kelaziman yang membeku ... ingin melihat masyarakat sewaktu-waktu disegarkan oleh pikiranpikiran dan pendapat-pendapat baru yang bisa merangsang masyarakat untuk terus memelihara dinamikanya."

${ }^{15}$ One example of renewed interest in a folk tradition is the popularity of lenong as a result of Sumantri Sastrosuwondo's work in adapting lenong to contemporary theater in the early 1970s. Lenong which was previously considered a low-class art form became accepted and enjoyed by the middle and educated upper classes of Jakarta. S. M. Ardan and D. Djajakusma produced popular lenong dramas at TIM, and Putu patterned his drama, Blong, which was produced in 1977, on lenong.
} 
novels, short stories, and dramas are cited in support of the contention that, despite a lack of realism in his work, Putu addresses questions of social import in Indonesia

Lack of Realism. Stylistically, Putu's writings since the early 1970s have departed from the generally accepted conventions of realism in Indonesian prose. He created dream-like sequences through the use of stream-of-consciousness techniques in his early novels, Telegram and Stasiun, ${ }^{16}$ The dream-like sequences present images from which the reader must create associations to events in his/her daily life. Narrative coherence is a function of themes, emotions, and images, not a function of temporal sequencing or the development of a plot and characters. This style focuses attention on thoughts and emotions, not on actions. Throughout the 1970s Putu's language became increasingly colloquial, fast-paced, and Jakartan. Often the organization of discourse was dream-like, frustrating easy interpretation. The dialogue was sprinkled with illogical and disconnected statements, making it ambiguous and sometimes humorous. In the story "Dream," Pian, who has been careening the streets of Jakarta all night, suddenly exclaims:

Why'd I end up like this? D'you want me to sell this dream to Russia, to America? So come on, gimme a break, gimme a second chance. ${ }^{17}$

This illogical sequence is reminiscent of the confusion in a dream, in contrast to the realistic fashion in which the story has been presented up to this point. The reader begins to wonder if Pian's story is real or only a dream. In this manner, Putu emphasizes the irrationality and confusion in daily life and the difficulty of distinguishing between the real and imagined worlds we inhabit.

Connections with Regional Arts. Beginning in the late 1970s, Putu began modifying the stream-of-consciousness style, stressing strategies from regional art forms. The strategies he used include indirection, humor, and fantasy. ${ }^{18}$ An other-worldly or fantasy setting is supported by a lack of character development and an absence of personal names. His use of roles and qualities-mother, policeman, someone, the sympathetic one-for names helps create flat, two-dimensional characters, not individuals. 19

A marked shift away from Western literary models occurred in Putu's work in 1975 with the productions of Lho and Nol neither of which had a written script. Putu began to realize that theater could move away from dependence upon the word. It could appeal to an audience on visceral, emotional, and non-intellectual levels by decreasing its use of discursive language. I interpret this move as a move toward the tontonan model found in regional performances (see below).

Since the mid-1970s, Putu has also emphasized an appeal to visual and auditory senses, creating a dependence on images and their associative powers rather than on

16 Telegram (Jakarta: Pustaka Jaya 1973); Stasiun (Jakarta: Pustaka Jaya, 1978).

${ }^{17}$ See "Dream," trans. M. Bodden, in Bomb: Indonesia Short Stories, ed. Rafferty and Sears, pp. 190-91.

${ }^{18}$ For a discussion of Putu's novel, Nyali (Jakarta: Balai Pustaka, 1983), see Amrih Widodo 'The 'Roh' of the System: On the Unification of Meaning and Expression in a Contemporary Indonesian Novel," Indonesia 40 (October 1985): 75-88. Widodo explores Putu's use of indirection and avoidance of entrapment in the "language system" in order to make the reader uncomfortable and force him/her to actively search for meaning in the novel.

${ }^{19}$ See Kuntowijoyo, "Penokohan dan Perwatakan Dalam Sastra Indonesia," in Budaya Sastra, ed. Andy Zoeltom (Jakarta: Rajawali, 1984); and Toda, "Teater Baru Indonesia," p. 42, both of whom discuss the lack of psychologically real characters in wayang stories and folk tales. 
logic and rationality as a means of communicating. In his dramas, he accomplishes this by "painting" riotously colorful and busy scenes, punctuated by numerous and contradictory voices, creating a cacophony that stuns the senses. Borrowing from genres such as wayang, he began to use clowns as wise interpreters to speak directly to audiences as well as to fellow actors. The clowns emphasized humorous routines, a feature of increasing importance in Putu's work. He borrowed illogical, humorous routines from contemporary folk comedians, such as the late Johny Gudel of Srimulat. In addition, the use of black humor, the grotesque, and the lewd-all found in numerous regional genres-are distinctive features of Putu's style in the 1980s. These features are aimed to appeal to a broad spectrum of society from diverse class, ethnic, and educational backgrounds.

By simultaneously presenting a number of "distorted" perceptions of the world, Putu creates a spectacle that blends modern Jakartan and traditional Balinese and Javanese images. Members of the audience are left to create for themselves the associations to connect Putu's literature with the concrete events of their own world. It is through these associations rather than through direct argumentation that the audience is invited to find meaning in the plays.

Tontonan. ${ }^{20}$ A significant adaptation from regional genres has been the incorporation of tontonan in Putu's theater. The meaning of the word tontonan covers a wide semantic domain; in its most general sense tontonan defines planned and unplanned events that attract attention. Street events such as the entertaining routine of a medicine man, a soccer game, and individual faux pas are all tontonan. Putu uses this term for his productions instead of the Indonesian word sandiwara, "drama," to emphasize an affinity with regional, oral genres which allow for audience participation and improvisation. In addition, Putu distinguishes his performance style from Western productions that are based on set scripts and a realistic acting style. A tontonan does not carry with it the presuppositions of drama as a written, "high" art form. Tontonan events are designed to adapt to local needs and resources and to facilitate interaction among participants. Tontonan is not a theory of performance but rather an attitude about the role of art in society; art is created by and for a local community.

Absence of Conclusions. Another element of regional genres which has been incorporated into Putu's dramas is their cyclic nature which disallows conclusions or final resolutions (See Putu's dramas, Aum [1982], Aduh [1972], and Front [1985]). The drama Aum begins and ends with a crowd scene in which a high government official is being asked imponderable questions by a group of bewildered subjects. This structure is reminiscent of the structure of the Balinese Calon Arong drama in which the conflict between the evil Rangda and the good Barong is never resolved; the characters wage an eternal struggle between good and evil. The return to the beginning in Putu's dramas is also reminiscent of the structure of wayang performances that begin and end at the king's palace. In these regional art forms, as in Putu's dramas, instead of a final victory there is a return to a state of balance between the abiding forces of good and evil.

The lack of a conclusion has been a feature of Putu's work since his early novels in the 1970s. In the novel Telegram, a young Balinese journalist living in Jakarta receives a telegram, notifying him of his mother's serious illness and imminent death. No major

${ }^{20}$ The noun tontonan is derived from the verb tonton meaning "to watch"; thus the noun refers to an event that attracts attention, a spectacle. For a discussion of tontonan see Ellen Rafferty, "The Tontonan Theatre of Putu Wijaya," in Putu Wijaya in Performance, ed. Rafferty. 
action occurs throughout the novel; instead the author explores the thoughts and emotions of a man caught between traditional obligations to family in Bali and desires and obligations of life in contemporary Jakarta. Questions of life-style and cultural identity, and feelings of loss and alienation are set within a dream-like world where chronology is vague and the real and imagined blend into one. The novel Stasiun offers a glimpse of a man in search of identity, purpose, and direction in life. Again no action occurs; even when the protagonist finally boards a train, having spent hours at the station, the reader is not certain of his destination. Stasiun explores the inner world of perceptions, recording the confused emotions and feelings of a wandering soul, not the accomplishments of a man of action.

A Discourse that Disturbs. The artistic strategies found in Putu's work are set in a discourse structure that surprises the reader with sudden shifts in time, mode, ${ }^{21}$ and perspective. Typically, Putu's stories are presented in language that is simple and direct; they are filled with events that are common, such as a petty theft, the death of a village woman, or the jealousy of a boss for his employee's uncomplicated life-style. These features persuade the reader that the story is part of his/her experiential world and foster a realistic interpretation. Even unusual events are presented in a straightforward, matterof-fact manner that encourages realistic interpretation.

When Oki woke up, there was a bomb next to him. It did not phase him at all, for he thought it was just part of his dream. He just reached out and hugged it like a pillow. 22

Not far into each story, Putu begins to distort the presentation by including sudden shifts in perspective, time, and mode; the resulting non-sequiturs and contradictions violate the reader's trust. Initial realistic interpretations are abandoned as confusion increases. This manipulation of the discourse structure obscures the boundary between real and imagined worlds, making interpretation difficult. The reader is forced to question the reality portrayed and to consider the subjective nature of "reality" itself.

An example of an unexpected change in mode is found in "Pian" where the activities of a petty thief are initially described in a realistic manner. Pian is depressed by his inability to achieve notoriety. In a final attempt to draw attention to himself, he decides to commit suicide by hanging himself atop a monument. In the last paragraph of the story, the reader discovers that the irrealis, not the realis, mode is being employed. The following two paragraphs demonstrate this unexpected shift.

Without hesitation, Pian tied a rope and carefully twisted it around his neck. Shouting "Freedom!" he jumped. His body dangled there, as the rain fell even harder. The streets were deserted, and nobody noticed the citizen of Jakarta who was killing himself.

The next day Pian ran to find a newspaper. But that story did not appear in the paper either. He waited several days but the story never appeared. Finally he began to believe. ${ }^{23}$

\footnotetext{
${ }^{21}$ Mode is a verbal category denoting the speaker's belief regarding the veracity of the activity of the verb. The mode may be realis, implying an actual event or irrealis, implying the conditional or counter-to-fact nature of the event.

22"If He Could Choose Again," trans. Michael Bodden, in Bomb: Indonesian Short Stories, ed. Rafferty and Sears, pp. 32-33.

23"Pian," trans. Lee Konrad, in ibid., pp. 70-71.
} 
The last paragraph makes it clear that the preceding one was in the irrealis mode. The abruptness of the change in mode, without discourse motivation or linguistic marking, creates surprise and uneasiness. Is the whole story to be read in the irrealis mode? Where did the shift occur? The shift raises the question of the subjectivity of perceived reality. To what extent do dreams shape reality and vice versa?

In "If He Could Choose Again," the discourse is manipulated through a change in time-frame. The main character, Oki, who has found a bomb in his bed, climbs a flagpole in an effort to distance the dangerous object from his family and friends. Until the final sentence, the story is related in the past tense; then the narrative is placed squarely in the present, including the reader within the time-frame. Below are the final two sentences.

Tortured by what he had done, Oki slowly died. His body hangs like a slice of dried meat on top of the flagpole to this very day. 24

This abrupt introduction of the present is bewildering. The motivation for the shift is not internal to the story; it is found in the pragmatic relation between the story and its audience. The shift forces the reader to reconcile his/her presence at the scene of this disaster. This raises questions, such as: In what sense is the audience a participant in this death and destruction? What responsibility does everyone bear?

Another type of change in discourse structure used by Putu to shock and disturb, is a shift in a character's perspective or attitude. In the drama Geez! such a shift occurs when the grieving wife of the recently deceased Bima, first expresses acceptance of the death saying:

Why are you all acting this way? Father wants to leave. Just let him. Come on, show

a little happiness, smile, laugh so that the person leaving will have nice memories.

Yet, a few minutes later she cries out:

Honey, don't go dear! Don't leave me! Don't leave us! Come home! Come baaack!25

The same type of reversal is apparent when Grandmother asks Bima to die and leave the family alone because they no longer want or need him. Her words are absurd, even ludicrous, because she makes the request for him to die in a tender and loving manner. The affect and the referential meaning of the dialogue are inconsistent.

Bima: $\quad$ But I'm not dead, yet.

Grandmother: Everyone already knows you're dead. What will they say if you're alive again? Where will they hide their faces? Everyone was praying you would die so that we'd have a little peace and quiet.

Bima: $\quad$ I don't want to die.

Grandmother: You have to! Your wife was very sad when you died. But she'll be even sadder if you're alive again because all her plans, all our plans, will be ruined. 26

Such reversals in attitude reflect either a lack of psychological reality or a situation of extreme stress. The second option may be discounted because similar reversals within this drama are too numerous. The audience begins to feel frustrated by the characters' lack of psychological reality. Characters cease to have any integrity or coherence as indi-

24"If He Could Choose Again," trans. Michael Bodden, in ibid., pp. 42-43.

25 See Putu Wijaya in Performance, ed. Rafferty, pp. 70, 71.

${ }^{26}$ Ibid., p. 114. 
viduals; no one in the story can be believed or trusted.

A final example of a shift in perspective is found in Putu's drama Aum (in English Roar). ${ }^{27}$ As the drama opens, a number of obscure questions are being asked of a district officer by a group of villagers who have come in search of answers. There is no linear plot line, merely sets of questions in a series of disconnected vignettes. The scenes are incongruous and.illogical, the regent is at one moment eager to help and at the next moment officious and arrogant. The villagers passionately engage in obscure village rituals and then begin to disco-dance. This incongruity causes one security guard to exclaim: "Wow sir, I hope this is only a dream." 28 The inability to distinguish "dream" from "reality" is a constant theme in Putu's work, and one that emphasizes the heterogeneity of perceptions in any community.

\section{Experimentation of the $1970 \mathrm{~s}$}

The departure from the accepted conventions of realism in Indonesian literature by Iwan Simatupang in the late 1960s and by Putu in the early 1970 s complemented the experimentation occurring at TIM in the 1970s. Through imaginary worlds no longer constrained by physical limitations, these writers explored the "inner realities" of the mind. The illogical and irrational were treated as a natural part of the human condition. But, although experimentation with non-realistic styles flourished in the 1970s, most Indonesian authors continue to use the conventions of realism. Prominent among such authors are Nh. Dini, Mochtar Lubis, Pramoedya Ananta Toer, and Mangunwijaya.

Since the early 1980s, there has been a reaction against the "fantasy" of experimental writers by critics such as Arief Budiman, Ariel Heryanto, and Emha A. Nadjib, ${ }^{29}$ who call for the writing of literature which is "relevant" and speaks about the "real" world in an easily comprehensible manner. According to these critics, experimental literature is more interested in aesthetics than in social messages. ${ }^{30}$ Further, these critics are dissatisfied with the prominence given experimental works (and the resulting exclusion of other works) by the government, press, and literary establishment. ${ }^{31}$ The literary establishment in Indonesia is seen as promoting a literature which avoids mention of actual social conditions, abrogating its role to improve society. Discussions of the role of literature in society are not new to Indonesia; vigorous debate occurred during Sukarno's Guided Democracy when the Institute of People's Culture (Lembaga Kebudayaan Rakyat, Lekra) promoted social realism. ${ }^{32}$ According to the critics of experimental literature, what is needed in Indonesia is not an abstract and "isolated" literature, but

\footnotetext{
27 "Aum" written in 1982, is an unpublished manuscript. Roar was translated by Michael Bodden in 1986 and was produced in Madison, Wisconsin, and DeKalb, Illinois by the experimental theater group, Broom Street Theater in 1986. It was produced by Putu Wijaya at Wesleyan University in the spring of 1987 and at La Mama in New York City in the spring of 1988.

28"Hansip: Aduh Pak semoga ini hanya mimpi." Putu Wijaya, ms., "Aum," p. 24.

${ }^{29}$ See Ariel Heryanto, ed., Perdebatan Sastra Kontekstual (Jakarta: Rajawali, 1985).

30 See Satyagraha Hoerip, "Mungkinkah-Sekarang-Kita Memiliki Kesusastraan Yang 'Lebih Terlibat'?" in Dua Puluh Sastrawan Bicara, pp. 102-10; Arifin C. Noer, "Sastra Kita Sastra Borjuis," in ibid., pp. 89-95; and Budiarto Danudjaya, "Dituntut: Seniman Sebagai Pemikir," in Budaya Sastra, ed. Zoeltom, pp. 117-26.

${ }^{31}$ See Keith Foulcher, "Sastra Kontekstual: Recent Developments in Indonesian Literary Politics," Review of Indonesian and Malaysian Affairs, 21, 1 (1987): 6-28, and Emha Ainun Nadjib, "Sastra Independen," in Budaya Sastra, ed. Zoeltom, pp. 137-50.

${ }^{32}$ See Keith Foulcher, Social Commitment in Literature and the Arts: The Indonesian "Institute of People's
} 
one that "dares" to speak out about social issues-a protest literature which is independent of the literary establishment.

In the debate about the role of literature in contemporary society, "isolated" literature is contrasted with "contextual" literature which is defined by Arief Budiman as follows:

The ideal type of contextual literature right now, according to me, is literature that is conscious of the social environment, that addresses the issues of injustice and poverty. But the essential meaning of contextual literature is works of literature that can be appreciated by the local audience. ${ }^{33}$

The meaning of the term "isolated" has shifted from the non-judgmental connotation of "limited audience" to the pejorative connotation of "not socially relevant and elitist." 34 Although I do not specifically address the issue of isolation in terms of the size of the audience, it is widely recognized that reading literature remains an activity of the educated elite. Clearly, literature does not reach the majority of citizens. Reflecting the view that "isolated" literature is not committed to social and economic change, ${ }^{35}$ literary critic David Hill commented in 1984 that:

New Order artistic champions, like Sutarji Calzoum Bachri, Danarto, and Putu Wijaya concentrated on fantastical and bizarre literary styles to obscure their lack of social commitment. ${ }^{36}$

Yet, other critics disagree, noting that both modern and traditional Indonesian literature contain social criticism even though that criticism may be veiled for political reasons. ${ }^{37}$

The reason for the above disagreement about the effect of experimental literature lies in structure of the literature. Experimental literature is seen as disengaged and as distant from the common people because its textual coherence is based on ideas presented by means of tropes. The interpretation of tropes (i.e. metaphor, metonymy, synecdoche or irony) demands analogic thinking to create associations between the images, symbols, and events of the story and events in the life experience of the reader. It is through these associations that the reader builds his/her interpretation of the text. The reader is thus asked to interpret, to make the analytic jump between the world of literature and contemporary society.

Culture" 1950-1965 (Clayton, Victoria: Centre of Southeast Asian Studies, Monash University, 1986).

33Untung Surendro, "Wawancara dengan Arief Budiman, Sastra Kontekstual dan Manikebu," in Horison 20, 3 (1986): 78. Surendro quotes Budiman, "Sastra kontekstual yang ideal pada saat ini menurut saya adalah sastra yang sadar akan lingkungan, yang membicarakan ketidak adilan dan kemiskinan. Tapi pengertian sastra kontekstual itu sendiri secara murni adalah karya sastra yang mampu dinikmati oleh lingkungannya."

${ }^{34}$ The term "isolated" was first used to describe Indonesian literature by Goenawan Mohamad in 1969 in "Tentang Keterpencilan Kesusastraan" reprinted in Goenawan Mohamad, Seks Sastra, Kita (Jakarta: Sinar Harapan, 1980): 39-49.

${ }^{35}$ The prominent exception is Rendra who, while experimental, makes direct attacks on government policies and actions and, therefore, is considered socially relevant. See for example his play translated and introduced by Max Lane, The Struggle of the Naga Tribe, Asian Pacific Writing 11 (St. Lucia: University of Queensland Press, 1979).

36David Hill, Who's Left? Indonesian Literature in the 1980s, Center of Southeast Asian Studies, Working Paper No. 33 (Clayton, Vic: Monash University, 1984), p. 2.

${ }^{37}$ See Sapardi Djoko Damono, "Kritik Sosial dalam Sastra Indonesia: Lebah Tanpa Sengat," in Kesusastraan Indonesia (Jakarta: Gramedia, 1983), pp. 18-32; and Paul Tickell, "Subversion or Escapism: The Fantastic in Recent Indonesian Fiction," Review of Indonesian and Malaysian Affairs 20, 1 (1987): 50-67. 
Although the role of the reader in interpretation is important in all types of literature, it is more critical in experimental literature where tropes are employed. While realistic literature demands interpretation because it is not simply a presentation of reality but an employment of literary conventions, it does not involve the analytic jump which tropes demand. Reader-response theory, which is increasingly popular in literary analysis, emphasizes the active role of the reader in the construction of meaning ${ }^{38}$. This theory replaces the objectivist tradition in which meaning is primarily grounded in the text and author; the authorial voice is the primary source of meaning. Critics of experimental literature in Indonesia appear to be promoting the objectivist tradition, espousing the belief that meaning is grounded in the author's intent ${ }^{39}$. This is but one theory of interpretation.

The objectivist theory is difficult to defend in the face of the cultural pluralism in contemporary society around the world, in particular in Indonesia. Increasingly there is no common ideological ground that provides interpretative authority to any one voice; rather, authority is more easily attributed to the multitude of readers who assign meaning. The reader may choose an interpretive framework from among the numerous theories being advanced today. New schools of interpretation such as feminist, Marxist, structuralist, and post-structuralist all provide possible frameworks; they all demand an ideological basis for interpretation. The ideological grounds for choosing one interpretation reflect the diverse socio-cultural contexts and historical backgrounds of readers.

\section{Meaning in Putu's Works}

The use of tropes in Putu's work allows for multiple interpretations of the thematic material depending on the reader's choice of interpretive framework. Putu's use of indirection does not mean he expresses no message and no concern for social and economic conditions. Both the meaning and relevance attributed to a text are indexical, that is partially dependent on what the reader brings to the text in terms of cultural and ideological background and partially dependent on the content of the text itself.

The question of relevance which is often raised in relation to contemporary Indonesian literature deserves some discussion. To be relevant "implies a close logical relation with, and importance to, the matter at hand." 40 In Putu's works, the logical connection with, and importance to, society are indirect, resulting from the use of tropes. Relevance is not stated directly because Putu does not refer to specific events and people in the world.

For example, the story "If One Could Choose Again" offers an example of how Putu uses symbols to offer multiple interpretations. On an emotional level, the story is at once incredible, humorous, and sad. Although the anecdote presented is a flight of

\footnotetext{
${ }^{38}$ See Roland Barthes, "The Death of the Author" in Image-Music-Text, trans. Stephen Heath (New York: New Hill and Wang, 1977); Stanley Fish, "Literature in the Reader: Affective Stylistics," in Is There a Text in This Class? (Cambridge: Harvard University Press, 1980); Wolfgang Iser, The Act of Reading: $A$ Theory of Aesthetic Response (Baltimore: Johns Hopkins University Press, 1978); Jonathan Culler, The Pursuit of Signs: Semiotics, Literature, Deconstruction (Ithaca: Cornell University Press, 1981); and Steven Mailloux, Interpretive Conventions: The Reader in the Study of American Fiction (Ithaca: Cornell University Press, 1982).

${ }^{39}$ Ariel Heryanto is an exception believing the reader must assume the work of interpretation.

${ }^{40}$ See Webster's New World Dictionary of the American Language (New York: The World Publishing Company, 1966), p. 1228.
} 
fancy-a distortion of everyday reality-the dilemmas, decisions, and contradictions presented in the story resonate with analogous occurrences in daily life. When Oki wakes up hugging a bomb, not his pillow, he is overcome by innumerable questions. As neighbors gather around the flagpole which Oki has climbed, communication breaks down; the crowd assumes the bomb is a child and begs Oki to drop the baby to the safety of their arms. In an attempt to save the "baby," a policeman shoots Oki and the bomb falls, exploding into the outstretched hands of family and friends.

For some readers, Oki may represent the citizen in a rapidly modernizing nation-a citizen confronted by the onslaught of technological advances that he does not comprehend. On the other hand, Oki may represent the Indonesian nation, misunderstanding and being misunderstood by a technological world at home and abroad. If both Oki and his family and friends are victims, where does guilt lie? Is the bomb a product (a baby) of a technologically advanced world which can not live harmoniously within the Indonesian context? The reader may consider-the power of technology, and its effects on social relations; the impossibility of avoiding contact with technology; and the impossibility of returning to the past or of "choosing again." The implications of these considerations for the reader create the story's relevance. If the reader can not make the analytic jump between the world of literature and daily life, then the literature is not relevant for him/her.

The story "Eyes" is of a deceased woman whose eyes are "lost" before she is buried. Her husband, family, and friends frantically seek help from government officials and the local shaman but to no avail. After searching in vain for a thief, the family is told by the shaman that reality is not as they had originally perceived it to be. ${ }^{41}$ Putu repeatedly encourages audiences to see the diversity of possible perceptions of the world. Perception and evaluation of events are personal matters; there is no one authoritative voice. Everyone is responsible for his/her own determination of meaning and relevance.

The story "Envy" focuses on a short conversation between a boss and his subordinate, in which the boss reveals his envy of the young man's honest and simple life-style. At the same time, the boss admits to his own loneliness, dishonesty, and despair; life's pressures have forced him to wear several masks. Incredulous at this outpouring of emotion, but respectful of his boss's status, the worker politely listens. Later when the worker is alone, he prepares to leave, peeling off one mask only to select another from the eleven he carries in his back-pack. The loneliness and alienation presented here are common themes in Putu's work and ones which invite a number of interpretations.

Despite the lack of communication between these men, the subordinate shows a great deal of empathy for his boss.

I could understand how sad the old man was. Maybe he was too weak to take all this. ... As he walked up the stairs, I watched closely and prayed he would find strength. Don't let him die on the stairs, having lost hope. ${ }^{42}$

Neither man can escape his world/masks; each views the other's reality as more comfortable and more truly human. Although a message of compassion for boss and subordinate emerges from the story, questions remain. Do these men represent social

41 "Eyes," trans. Ellen Rafferty, in Bomb: Indonesian Short Stories, ed. Rafferty and Sears, pp. 178-79.

42 "Envy," trans. Michael Bodden, in ibid., pp. 142-43. 
classes? Is the story critiquing language etiquette which disallows communication from lower to higher status individuals? Is the story critiquing behavior patterns of traditional society? The manner in which these themes are made meaningful and relevant will depend on the reader.

The themes of the inevitable passage of time and the aging process are found in the short stories "Old" and "Bisma," where changing social mores are examined. "Old" deals with an old man's resistance to loss of power. Confronted by an ambitious and belligerent young man, the old man is eventually overtaken. Only after defeat, does he realize the adversary is himself at a younger age. Does the old man represent the aging process or conflicts of power relations in which the enemy lies within? Does the young man's lack of interest in the old man reflect the significance of our lack of interest in our own histories for an understanding of ourselves? The absence of the logic of real-time chronology frees the reader to create numerous analogies with real-life situations.

In "Bisma" a brave warrior from Javanese wayang stories appears in Jakarta's Senen mall. He creates a great commotion by presenting a revisionist history of himself to a crowd of shoppers. Characteristically, Putu produces an illogical series of events which serves to blur the distinction between real and imagined worlds. The old man, Bisma, denies his heroic qualities and explains how he has been misunderstood by modern society. ${ }^{43}$ Having presented his revisionist autobiography, Bisma strips off his wayang costume, dons jeans, $t$-shirt and sun glasses, announcing that he has changed his name from Bisma to Bhasmy, 44 and disappears into the crowd. Although most feel no need for the old Bisma or for his values, others are impelled to call for his return. The tensions between the need for change and the need for continuity with traditional values are addressed through tropes. As in all of Putu's works, the ending offers no conclusion, but merely invites questions.

The reader is left to ponder: How does one reconcile contradictory social values in a society? When are old customs to be considered no longer valid? How is one to approach the interpretation of historical events that must be framed within the values of another period? Are those who call for Bisma's return only interested in his trappings or in his values and spirit? Can a traditional set of values harmoniously coexist with modern society and values? At another level of analysis, these same questions can be directed at Putu's writings: How can traditional modes of expression and modern contexts complement one another in contemporary literature?

\section{Concluding Remarks}

Putu's literary style reflects strategic choices for speaking in the contemporary sociopolitical environment of Indonesia, an environment constrained by both audience composition and larger social and political forces. His decisions regarding style must be understood as a product of his own life experience of Bali in the 1950s, of political upheaval in Yogyakarta in the 1960s, of Jakarta in the 1970s and 1980s, and of his residencies abroad in Japan in 1972, and in the United States in 1974-1975 and 1985-1988.

Putu's desire to leave much of the work of interpretation to the reader through the use of tropes is a means of creating a dialogic relationship with the audience, an asser-

43"Bisma," trans. Ellen Rafferty, in ibid., pp. 216-17.

${ }^{44}$ The name Bhasmy sounds like the Indonesian verb basmi, meaning to erase or eradicate. 
tion of the importance of the reader's voice and authority, and a down-playing of his own authorial voice. This is a risky choice for an author, because it makes the reader's job more difficult and thus limits audience appeal. The reader must choose an interpretive framework and bring to the story his own experiences, associations, interpretations, and evaluation of relevance.

Although the voice of the reader assigns meaning, this does not negate Putu's voice as one among many. In the drama Geez! Putu speaks out against self-serving, egotistical interests and speaks for a humane and tolerant society, one accepting of diversity. Yet, the message is not tied to specific events in Indonesia; the reader is free to interpret the message to fit his/her own situation. The request for audience participation is an implicit expression of respect for the reader who must be independent (mandiri). ${ }^{45}$ In response to the question of the responsibility of the artist for effecting social change, Putu supports the reader-response theory of literary criticism, stating:

That question can not be asked of the work itself because it is "dead." The answer lies in the reader. The question which must be asked is, can a particular society or reader make use of a literary work. 46

45 "Mandiri" is the name of Putu's theater group in Jakarta.

46Wijaya, "Konsep," in Dua Puluh Sastrawan Bicara, pp. 84-85. "Pertanyaan itu tidak bisa ditanyakan kepada karya itu sendiri. Karena itu adalah barang 'mati.' Jawabannya ada pada manusia pembacanya. Pertanyaan yang mestinya diucapkan adalah apakah satu masyarakat tertentu, apakah pembaca, sudah dapat memanfaatkan karya sastra?" 